\title{
Pathological and Molecular Characterization of Lymphocystis Disease Virus (LCDV) In Sea Bream Fish in Egypt
}

\author{
Aly S. M. ${ }^{(1)}$, Shimaa M. Mansour ${ }^{(2)}$, Randa Y. Thabet ${ }^{(3)}$ \\ (1) Department of Pathology, Faculty of veterinary Medicine, Suez Canal \\ University. (2) Department of Virology, Faculty of Veterinary Medicine, \\ Zagazig University. (3) Department of Aquaculture Diseases Control, Fish \\ Farming and Technology Institute, Suez Canal University.
}

\begin{abstract}
Hypertrophied nodules or papilloma like lesions were detected in the skin and fin of Sea bream farms (at Mothalath El Deba and Bardaweil Lake) in Egypt with morbidity rate reached to $70 \%$ and mortality rate up to $40 \%$. A total of 20 affected cultured sea bream samples were collected for laboratory examinations. Histopathological examination revealed intracytoplasmic basophilic inclusion bodies in the skin and fins lesions. In addition, a thick hyaline capsule surrounding the hypertrophied fibroblast and contain heavily enlarged cells (lymphocystis) with necrosis and inflammatory response. PCR results with primers specific for the gene encoding major capsid protein (MCP) gave a predicted amplified product at $405 \mathrm{bp}$ fragment by agarose gel electrophoresis. The current results encourage further investigations for this virus in Egyptian farms and recommend the development of prevention strategies against LCDV in Egypt.
\end{abstract}

Key words: Sea bream, Egypt, Iridovirus, Lymphocystis disease virus, Histopathology, Molecular detection, PCR, phylogenetic analysis.

\section{Introduction}

Aquaculture has been practiced in Egypt for millennia, but modern approaches have recently been adopted to maximize its output. Today, aquaculture production in Egypt is the largest in Africa with about one million tonnes per annum (Shaalan 2018). Fish has become an important resource in Egypt to meet the food and nutrition security needs for the rapidly expanding human population (Aly, 2013). Fish is a food of excellent nutritional value, providing high quality protein, a wide variety of vitamins and minerals, a range of micronutrients, and fatty acids particularly the omega- 3 fatty acids essential for human brain 
development and reproduction (Tacon and Metian, 2013) because they are required for fetal and infant growth, maturation and cognitive development (Michaelsen et al., 2011). They are also often the cheapest and most frequently consumed animal-source food in low income food deficit countries (World Bank, 2006), making an important contribution to diversity in otherwise monotonous diets dominated by starchy staples (Thilsted, 2013). In developing countries, fish contribute about $30 \%$ of the total consumption of animal protein per capita (Wang et al., 2015). Marine fish production in Egypt contributes to about $70 \%$ of the total production of marine fish from North Africa as most of the North African countries depend on fishery catches rather than aquaculture (Rodger and Davies, 2000; Mustapha et al., 2014). Many challenges face the development of mariculture in Egypt and it is important to determine the constraints and limitations facing the development of this industry and plan to alleviate these issues wherever possible. The most important obstacles hindering sustainable aquaculture development in Egypt are viral diseases which are incriminated for high economic losses and mortalities in fish farms. Besides mortalities, fish viral pathogens have a negative impact on feed conversion rates and total body weights of recovered fish post infection (Shaalan et al., 2018). Viral infections are more difficult to control due to the high susceptibility of aquatic animals to them at an early age, limited availability of therapeutics, insufficient knowledge about pathogenesis of virus infections and limited knowledge about natural resistance mechanisms in aquatic animals. In Egypt, there is not enough information about the real map of viral infections and distribution in fish due to lack of surveillance program for monitoring of viral infections in fish (Shaalan et al., 2018). Major disease problems affecting gilthead seabream farms is lymphocystis disease, the most frequently reported viral infection in farms in the South Atlantic and Mediterranean areas (Borrego et al., 2001; Colorni \& Padros, 2011). Lymphocystis disease (LCD) is a self-limiting condition characterized by the appearance of hypertrophied fibroblasts in the connective tissue of fish, primarily in the skin and fins. The causative agent of the disease is the Lymphocystis disease virus (LCDV), a member of the Iridoviridae family, belonging to Lymphocystivirus genus. LCDV genome is a single linear doublestranded DNA molecule (Jancovich et al., 2012). LCDV is a large icosahedral non-enveloped viral particle may vary in size from 120 to $340 \mathrm{~nm}$ in diameter (Tidona \& Darai 1999; Paperna et al., 2001). Development of the 
disease is usually associated with several environmental factors and, more frequently, with stress conditions. In gilthead seabream, LCD-associated lesions have been described only in the fish skin and fins, and usually disappear after 2045 days depending on water temperature (Paperna et al., 1982; Gonzalez de Canales et al., 1996; Kvitt et al., 2008). In Egypt, few published studies addressed the marine fish diseases. Accordingly, it is important to investigate the current situation of the emerging viral diseases among cultured marine fish in Egypt. The present study aimed to diagnose LCDV among cultured gilthead seabream (Sparus aurata) through clinical signs, postmortem lesions and histopathologically as well as molecular biology investigation.

\section{Materials and methods}

A total of 20 clinically infected sea bream fish samples were collected from Egyptian farms at Mothalath El-Deba, Damietta Province and Bardaweil Lake, North Sinai Province (10 fish each) during the period from January to April 2017. The collected fish showed multifocal to diffuse white, round, firm, papilloma or tumor like nodules on the skin of the body, fins, eyes and mouth easily detected by naked eye with mortalities up to $40 \%$. The collected tissue specimens of fish (skin, muscle, fin) were used for histopathological examination, molecular detection and sequencing.

\section{Histopathological examination}

All collected sea bream fish were cleaned, washed three times in sterile distilled water and dried thoroughly with sterile towels. The collected tissue specimens (skin, fins, hepatopancrease) were fixed in $10 \%$ neutral buffered formalin for 48 hours, then washed under running water and dehydrated by using increased graded concentrations of ethyl alcohol. The specimens were cleared by xylene then blocked in paraffin. Five micron thick paraffin sections were prepared and stained with hematoxylin and eosin. The sectioned were mounted in Canada balsam and covered with cover slips, then examined microscopically (Suvarna et al., 2013).

\section{Fish samples for PCR}

\section{DNA extraction kits}

A part of skin, muscle and fin are kept in separate containers at $-20^{\circ} \mathrm{C}$ for DNA extraction and diagnosis of Lymphocystis disease virus with PCR. Total DNA were extracted by following the manufacturer instructions of the extraction Kits GeneJET Genomic DNA Purification Kit (Thermo scientific, UK).

Gene amplification reaction conditions for LCDV MCP gene Oligonucleotide Primers according to Kvitt et al., (2008):

F 5' TTTGAATGGGAGGATCAC 3'; R 5' TCCGTAAATGCTGTTAGC 3'. that were targeting (405 bp) the 
complete ORFs of structural major capsid protein of LCDV. The PCR was performed in a total volume of $50 \mu \mathrm{l}$ in a sterile $0.2 \mathrm{ml}$ RNase free PCR tube using $2 \mathrm{X}$ DreamTaq ${ }^{\mathrm{TM}}$ PCR Master Mix (Thermo scientific, UK). The solution phase PCRs contain the following contents: Master mix (including DNA polymerase $+10 \mathrm{mM}$ dNTP mix) $25 \mu l$, Forward primer $(50$ pmole) $1 \mu 1$, Reverse primer (50 pmole) $1 \mu 1$, DNase free water 20 $\mu 1$, Template (cDNA) $3 \mu 1$ with a total $50 \mu 1$.

The optimized PCR cyclic reaction conditions were performed according to Poulos and Lightner (2006) in Creacon, Thermo cycler, Holand and described as follow: 1 cycle of an initial denaturation at $95^{\circ} \mathrm{C}$ for 2 minutes and followed by 39 cycles of denaturation at $95^{\circ} \mathrm{C}$ for 30 seconds, annealing at $65^{\circ} \mathrm{C}$ for 30 seconds and elongation at $72^{\circ} \mathrm{C}$ for 30 seconds. The PCR amplification was completed using 1 cycle of final elongation step at $72^{\circ} \mathrm{C}$ for 10 minutes then cool incubation at $4^{\circ} \mathrm{C}$.

\section{Gel electrophoresis}

Fifty $\mathrm{ml}$ from $1.5 \%$ agarose was prepared in 1x TAE buffer by heating in microwave. The melted agarose was left to cool to about $45^{\circ} \mathrm{C}$. $50 \mu 1$ from ethidium bromide (stock $=0.5 \mathrm{mg} / \mathrm{ml}$ ) was added to give a $0.5 \mu \mathrm{g} / \mathrm{ml}$ as final concentration. The gel was poured. After complete solidification of agarose, the comb was removed then $1 \mathrm{X}$ TAE buffer was added.
Five $\mu 1$ of the PCR products and 5 $\mu 1$ molecular weight marker were added into the marked wells formed in gel. Electrophoresis was done at 100 volts for $40 \mathrm{~min}$ then the gel was viewed and photographed on the UV transilluminator. Gel documentation system (Geldoc-it, UVP, England), was applied for data analysis using Totallab analysis software Ver.1.0.1 (www.totallab.com).

\section{Partial sequencing:}

Purification of specific PCR amplicons from agarose gel:

The PCR amplicons (405 bp) was considered specific bands for LCDV. The amplified PCR products were purified using QIAEX II Gel Extraction Kit (QIAGEN, USA) following the manufacturer's instruction.

Specific bands were excised using a clean scalpel. The gel slices were weighed. Three volumes of Buffer QX1 were added to 1 volume of gel for DNA fragments. (For example, $300 \mu 1$ of Buffer QX1 was added to each $100 \mathrm{mg}$ of gel). A $30 \mu \mathrm{l}$ of QIAEX II was added to the sample. The tubes were incubated at $50^{\circ} \mathrm{C}$ for $10 \mathrm{~min}$ to solubilize the agarose and bind the DNA. The samples were centrifuged for 30 seconds at $13000 \mathrm{rpm}$. The supernatants were carefully removed with a pipette. A $500 \mu 1$ of Buffer QX1 were added to the pellets. The pellets were resuspended by vortexing. The tubes were centrifuged for 30 seconds at $13000 \mathrm{rpm}$. The supernatants were carefully 
removed with a pipette. A $500 \mu l$ of Buffer PE were added to the pellets. The pellets were resuspended by vortexing. The tubes were centrifuged for 30 seconds at 13000 rpm. The supernatants were carefully removed with a pipette. The washing process with Buffer $\mathrm{PE}$ was repeated twice to remove residual salt contaminants. The pellets were kept for 30 min for airdryness.

The DNA was eluted by addition of $20 \mu \mathrm{l}$ of Tris buffer. The pellets were resuspended by vortexing. The tubes were incubated at room temp for $5 \mathrm{~min}$, centrifuged for 30 seconds at $13000 \mathrm{rpm}$. The supernatants containing the purified DNA were carefully transferred to a clean tube.

\section{Sanger sequencing:}

The purified PCR products were sequenced using the same forward and reverse primers used in PCR (Delta

Scientific

Consultancy Center, Alexandria, Egypt). Forward and reverse sequences were aligned together to generate a consensus sequence using DNA Baser Sequence Assembler version $\quad 4.36$ (http://www.dnabaser.com/). The obtained sequences were further identified by nucleotide BLAST (http://www.ncbi.nlm.nih.gov/BLA $\underline{\text { ST). }}$

Sequence and Phylogenetic analysis:

The nucleotide sequences obtained from the PCR products were aligned with other viral sequences available in GenBank (http://www.ncbi.nlm.nih.gov/) of the National Centre for Biotechnology Information (NCBI). Comparative alignment of nucleotide sequences was performed using ClustalW using MegAlign module of DNAStar software (Lasergene version 7.2, USA). The phylogenetic tree was generated using neighbour-joining method employing the Kimura 2parameter correction in MEGA version 5 (www.megasoftware.net) by aligning the nucleotide sequence of virus genes with other sequences available in the GenBank with 1,000 bootstrap analyses.

\section{Results}

\section{Gross Pathology}

Diseased fish showed multifocal to diffuse white, round, firm, papilloma or tumor like nodules on the skin of the body, fins, eyes and mouth (Figure 1). Hypertrophied cells and abnormal growth (white colour nodules) in the outer skin of the fish as can easily be detected by necked eye. Infected sea bream showed pale colour and some petechial hemorrhage in the internal organs

\section{Histopathological findings:}

Many clusters of Lymphocystis cells (hypertrophied fibroblasts cells) were seen in the connective tissues of the epidermis at fins and skin. Numerous hypertrophied cells with basophilic intracytoplasmic inclusion bodies were observed in the dermal connective tissues where 
they were surrounded by an abundance of inflammatory epithelioid cells. The lymphocystis hypertrophied cell was surrounded by a thick smooth hyaline capsule. The nucleus of lymphocystis cell was enlarged, irregular and containing basophilic marginated chromatin. LCDV infected cells were irregular, round and connected with each other and some lack their nuclei. A summary of histopathological findings in sea bream fish lesions was shown in Figure (3) and Table (1) and were characteristic for LCDV. Regarding, No characteristic lymphocystis lesions were detected in the internal organs, but variable histopathological alterations were observed. Hepatocytes showed vacuolization and increased cytoplasmic basophilia with some areas of necrosis.

III- PCR results of WSSV in shrimp samples

Single-step PCR results with primers specific for the gene encoding MCP gave a predicted amplified product at $405 \mathrm{bp}$ fragment by agarose gel electrophoresis as observed in Figure (4) and Table (2). This PCR product was obtained from 4 LCDV samples that were previously suspected by gross lesions and histopathology as being infected with LCDV. These samples represent isolates from two localities in Egypt including; Bardaweil Lake and Mothalath El Deba.
The amplified PCR products in LCDV of infected sea bream fish samples based on the gross lesions and histopathology revealed 2 out of 4 fish samples were PCR positive.

Sequences and phylogenetic analysis of LCDV:

To assess genetic characteristics of LCDV samples and identify specific viruses for further characterization, sequencing and comparative analysis was performed. A primer pair that amplifies a 405 base pair fragment of the encoding region was used to sequence the variable regions of LCDV samples. Two fish samples were chosen for genomic sequencing and nucleotide BLASTn analysis from both localities. The percent of identity of nucleotide sequences of our samples was $96 \%$. Comparative alignment of nucleotide sequences showed that, the two samples shared similarity 80-89.7\% with LCDV sequence from Korea, Canada, USA, Tunisia and Israel.

To recognize the association of LCDV samples with further circulating LCDV, a phylogenetic tree based on the variable region nucleotide sequences of $12 \mathrm{LCDV}$ that are available in GenBank, was constructed using the neighbourjoining method. The tree (Figure 5) showed that our samples were closely related to LCDV isolate from Korea (AY823414), LCDV isolate from Canada (GU939626), LCDV isolate strain Leetown NFH 
from USA (GU290550), isolate

LCDV-SA-Eilat from Israel LCDV strain SA1.ETun.2011 from (EF184306).

Tunisia (HE650105) and isolate

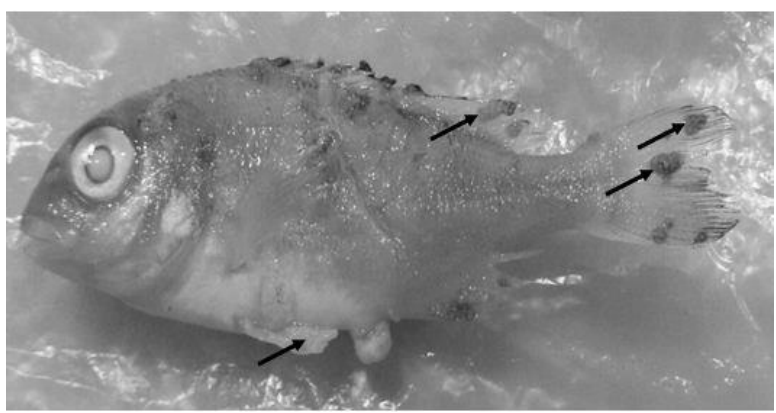

Figure 1: Sea bream fish showing multifocal to diffuse white, round, firm, papilloma or tumor like nodules on the skin of the body and fins (Arrows).

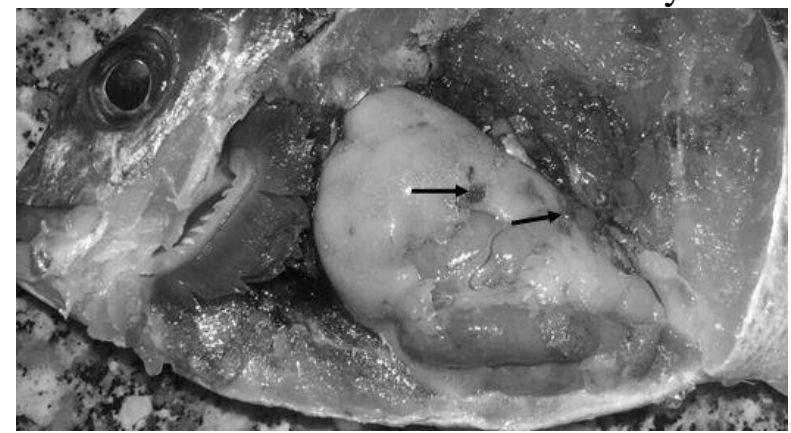

Figure 2: Sea bream fish showing pale liver with petechial hemorrhage (Arrows).

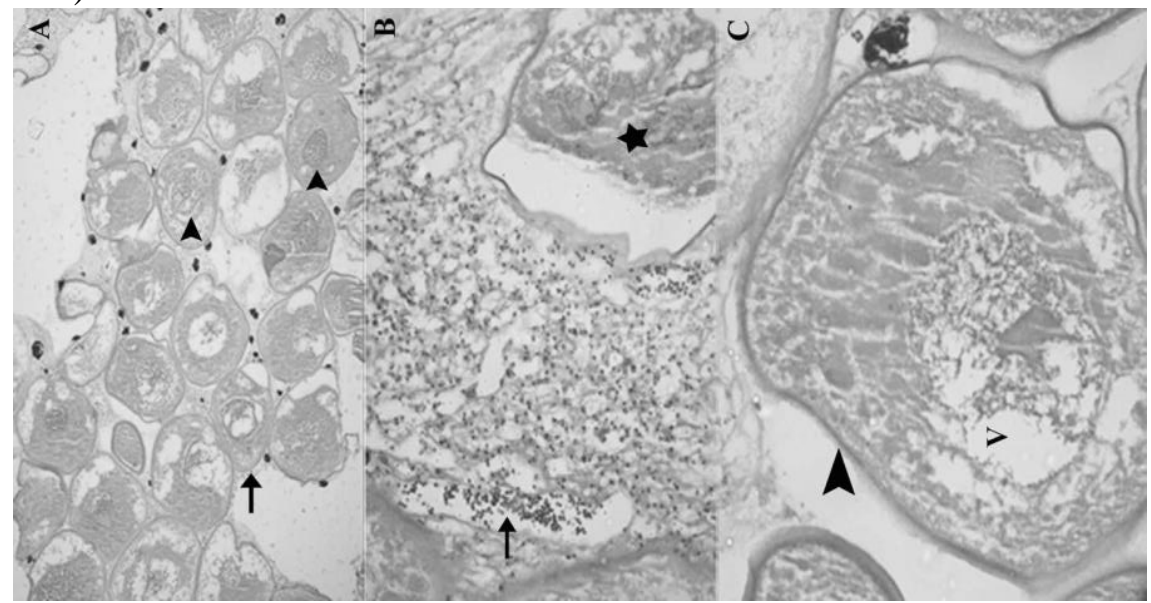

Figure 3: Histopathological examination of sea bream suspected to be infected with LCDV (H\&E). (A) Fish dermis tissue showing lymphocystis in several developmental stages with numerous hypertrophied cells 
containing basophilic intracytoplasmic inclusion bodies (Arrow head) surrounded by a thick smooth hyaline capsule (Arrow) in the connective tissues of the dermis X400. (B) Lymphocystis hypertrophied cell showing hyaline necrosis and vacuolization (Star) with inflammatory cells (Arrow) X400. (C) Lymphocystis hypertrophied cell was surrounded by a thick smooth hyaline capsule (Arrow head), showing vacuolization (V) and the nucleus was enlarged, round, irregular and containing basophilic clumped chromatin X400.

Table 1: Scores of histopathological lesions in 20 collected sea bream fish suspected to be infected with LCDV:

\begin{tabular}{lc}
\hline Histopathological lesions & LCDV \\
\hline Necrosis in dermis, epidermis & ++++ \\
I/N inclusion bodies & - \\
I/C inclusion bodies & +++ \\
Vacuolar degeneration & + \\
Lymphoid organ spheroids (LOS) & ++ \\
Zenker's necrosis & +++ \\
Cellular degeneration & +++ \\
Nuclear hypertrophy & +++ \\
Pyknosis and karyorrhexis & +++ \\
Lymphocytic infiltration & +++ \\
Accumulation of fluid (edema) & +++ \\
Degeneration \& hypertrophy & + \\
Lymphocystis cells (hypertrophied fibroblasts cells) & ++++ \\
Inflammatory cells & ++++ \\
Thick smooth hyaline capsule & ++++ \\
Enlarged, irregular cells and nucleus & and containing \\
basophilic marginated chromatin & ++++ \\
Altered shape of Hepatocytes & \\
Hyaline degeneration & ++++ \\
Signs of vacuolization & ++++ \\
\hline
\end{tabular}

The criteria of scoring were done according to Shackelford et al., (2002):

++++ Severely affected (100\% of examined samples have lesions)

+++ Highly affected (75\% of examined samples have lesions)

+ Moderately affected (50\% of examined samples have lesions)

$+\quad$ Mild affection (25\% of examined samples have lesions)

- $\quad$ No affection (no lesion in all examined samples) 


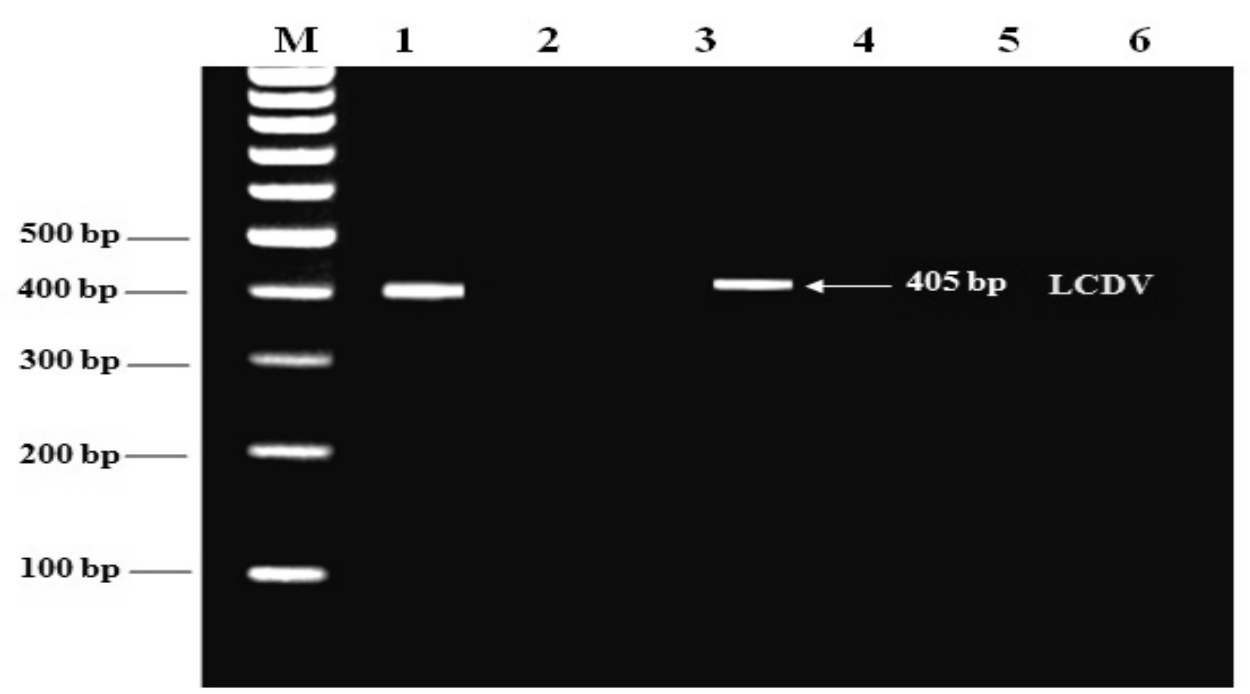

Figure 4: Molecular detection of LCDV in sea bream fish using PCR. The amplified products from fish tissues following $1.5 \%$ agarose gel electrophoresis and ethidium bromide staining. M: DNA marker (100 bp), lane 1 and 3: Positive LCDV samples, lane 2 and 4: Negative samples, lane 5 and 6: Negative control.

Table 2: Molecular detection of sea bream fish virus (LCDV) using PCR in samples collected from Mothalath El Deba and Bardaweil Lake, during 2017

\begin{tabular}{|c|c|c|c|}
\hline \multirow{2}{*}{ Locality } & \multicolumn{3}{|c|}{ Fish (LCDV) } \\
\cline { 2 - 4 } & $\begin{array}{c}\text { Total No. of } \\
\text { samples }\end{array}$ & $\begin{array}{c}\text { No. of Pooled } \\
\text { samples }\end{array}$ & $\begin{array}{c}\text { No. of Positive } \\
\text { samples }\end{array}$ \\
\hline Mothalath El Deba & 10 & 2 & $2 / 2$ \\
\hline Bardaweil lake & 10 & 2 & $0 / 2$ \\
\hline
\end{tabular}




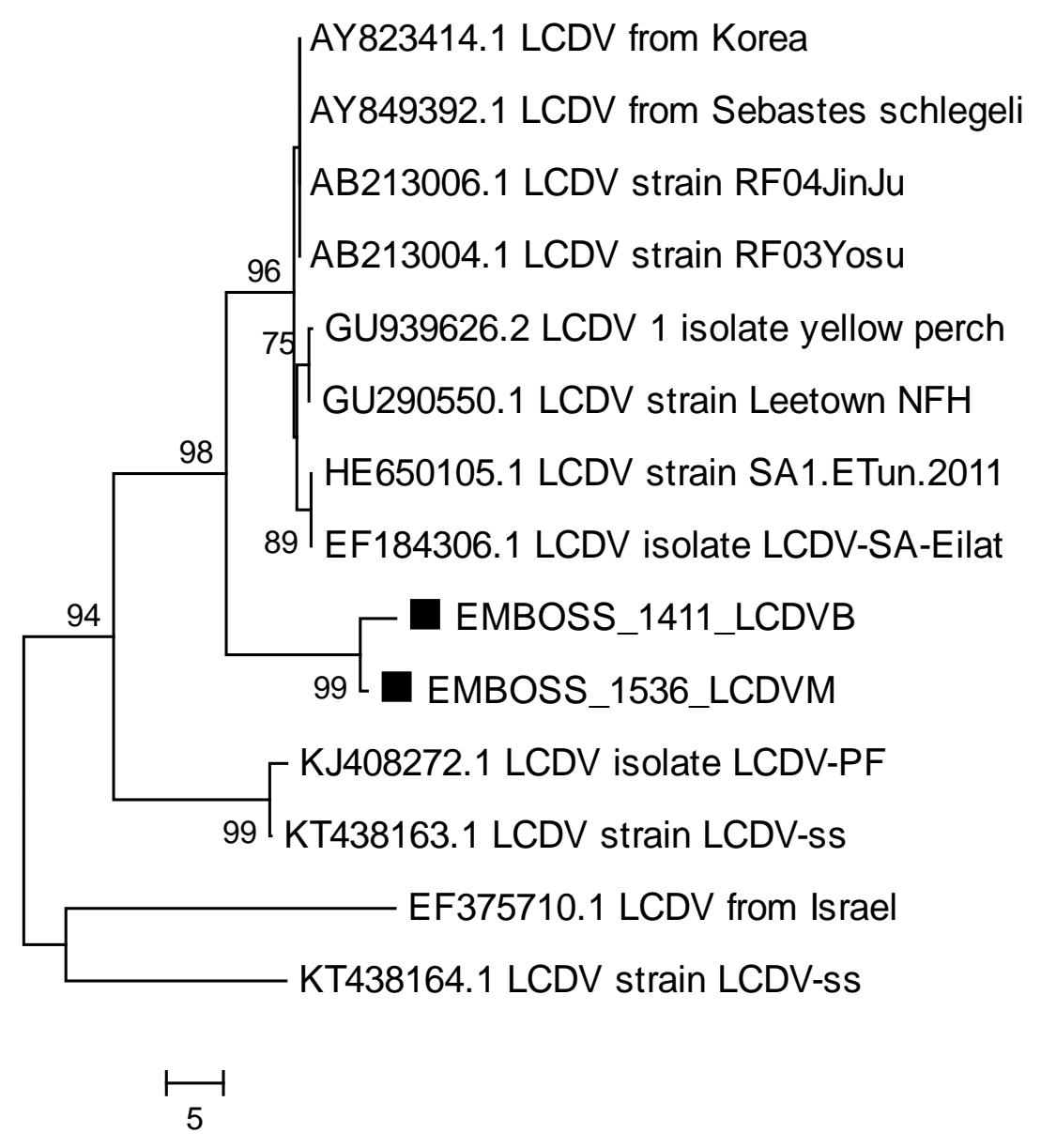

Figure 5: Phylogenetic tree of LCDV based on a partial nucleotide sequence. The tree was constructed using the Neighbor-joining method in MEGA5. The robustness of individual nodes of the tree was assessed using 1000 replications of bootstrap re-sampling of the originally aligned nucleotide sequences. Bootstrap values $\geq 70 \%$ is shown above the branches. The virus isolated in this study is marked with solid quadrilateral.

\section{Discussion}

Emerging disease epizootics frequently cause substantial, often explosive, losses among populations of shrimp and fish, resulting in large economic losses in commercial aquaculture and threats to valuable stocks of wild aquatic animals (Walker \& Winton, 2010). A large number of pathogens threaten the fish aquaculture industry with a majority of these being viral in etiology, so viral illnesses constitute the main problem faced by penaeid shrimp and seabream fish farms worldwide 
(Verônyca Coelho-Melo et al., 2014). In Egypt, few published studies addressed the marine fish diseases. Accordingly, it is important to investigate the current situation of the emerging viral diseases among cultured marine fish in Egypt.

To better understand the circumstances of some emerging viral diseases among fish farms in Egypt, twenty fish were collected from Mothalath El Deba, Damietta Province as well as Bardaweil Lake, North Sinai Province that were examined for clinical signs of disease and then investigated for the presence of viral infection. Under field conditions, it was possible to suspect clinically affected seabream fish. The gross lesion and histopathological pictures were recorded in some cases and later confirmed by molecular detection and sequencing of the viruses.

LCD outbreaks are frequently observed in the Mediterranean gilthead seabream aquaculture. Generally, viral diseased fish show low growth rates, which may be caused by the anemia generally associated with this disease as mentioned by Iwamoto et al. (2002), although it is usually described as a self-limiting disease, there are several reports on mortalities up to $45 \%$ in juvenile fish, which may be related to secondary bacterial infections or with particularly large growth of lymphocystis, which severely impaired fish osmoregulation, breathing or feeding, cannibalism and/or parasitic infestations (Colorni \& Padrós, 2011; HaddadBoubaker et al., 2013; Dezfuli et al., 2012). In heavily affected fish, lymphocystis may cover the entire body, spreading from the gills to the fins and less frequently, they have also been described on eyes, causing exophthalmia, and internally over the mesenteries, peritoneum and several internal organs as mentioned by Xing et al. (2006). LCDV is considered a dermotropic virus so diagnosis of LCD is generally based on typical skin lesion observation. In the current study, abundant and extensive nodules were seen all over the skin especially in the pectoral and dorsal regionas well as caudal fins of cultured sea bream fish. The pathognomonic signs of LCD include the appearance of small pearl-like nodules on the skin and fins that are usually grouped in clusters, papillomatous in appearance, and can cover the entire body surface of the fish as similarly reported by Wolf (1988). These nodules consist of LCDV-infected hypertrophied dermal fibroblasts (up to $1 \mathrm{~mm}$ in diameter), named lymphocysts or lymphocystis cells (Bowden et al., 1995).

Histopathological examination of LCDV-infected fish showed the presence of LCDV in the skeletal muscle and gill lamella. The cytoplasm of lymphocystis cells were changed, developing basophilic, intracytoplasmic 
inclusion bodies that appeared as dense vacuolated bodies with enlarged nucleus and cellular hypertrophy. In addition, a thick hyaline capsule surrounding the hypertrophied fibroblast was observed in the cytoplasm, especially in the mature lymphocystis cells as previously confirmed by Hossain and $\mathrm{Oh}$ (2011). Histopathological studies carried out in LC-diseased fish have been focused on the description of lymphocystis cells, with few reports dealing with histological observations of the internal organs, except when lymphocysts were also present (Sheng \& Zhan, 2004). In this study, LC-diseased gilthead seabream specimens showed lymphocystis cells only in the dermis of the caudal fin, with histological characteristics resembling those previously described in this fish species as recorded by Gonzalez de Canales et al. (1996). Histopathological alterations of varied severities were also observed in other organs, including necrotic changes in the liver and kidney, inflammatory response in the intestine and intraventricular hemorrhage. On the other hand, necrotic changes in the epithelium were the only histological alterations described so far in gilthead seabream fishes affected by LCD (Cano et al., 2009). In the present study, hepatocytes showed vacuolization and increased cytoplasmic basophilia with some areas of necrosis.

The second approach of this work was to molecularly detect the viral infection in diseased fish. Fish tissues were analyzed by PCR using primer set to LCDV. Although these methods are quite accurate, they are too expensive to be used viably as mentioned by Mello et al. (2011). The availability of sensitive and specific tests for detection of pathogens in sea bream fish is essential for accurate diagnosis of diseases affecting cultured population. PCR is a rapid, sensitive and highly specific detection method for fish viruses, which can be a powerful tool to detect iridovirus infections; LCDV in sea bream fish as reported by Mao et al. (1997). A primers set was used to detect 405 bp amplicons in LCDV using PCR. The primers was shown to be specific for Major capsid protein (MCP) gene of LCDV and no amplicons were detected using DNA extracted from sea bream fish infected with other fish viruses as indicated by Kvitt et al. (2008). The PCR has been used to amplify a portion of LCDV genome using specific primer as stated by Kvitt et al. (2008). It was used for definite identification of LCDV and the results showed higher sensitivity to detect the LCDV like those described before. In this study, 20 samples were collected, pooled together in 4 tubes and submitted to DNA extraction using specific primer to detect viral DNA in the 
tissue. 2 out of 4 samples were positive in LCDV from locality Mothalath El Deba, which showing that affection is high in this area than another one.

The PCR has been used to amplify a portion of LCDV genome using specific primer of MCP gene. It was used for definite identification of LCDV, the results showed higher sensitivity to detect the LCDV like those described before as recorded by Kvitt et al. (2008). In this study, 4 samples were collected, pooled together and submitted to DNA extraction and PCR using MCP gene specific primer to detect viral DNA in the tissue. 2 out of 4 samples were positive.

The third approach of this work was to assess genetic characteristics of viruses via nucleotide sequencing and phylogenetic analysis. Thus, nt sequence analysis is needed to completely identify the viruses of collected samples as stated by Mello et al. (2011). The phylogenetic tree based on sequence of specific gene for Lymphocystis disease virus showed that samples are clustered and compared with other related nucleotide sequences on Genbank. In Egypt, there are no records for LCDV until now.

In sea bream fish, LCDV of our samples was related to Korea, Canada, USA, Tunisia and Israel with homology 80-89.7\%.

Although the reported LCDV samples showed similar macroscopic and microscopic picture with those detected by Hossain and Oh (2011). However, low identity was reported between our nucleotide sequences and those published sequences derived from Korea, Canada, USA, Tunisia and Israel isolates, as the published sequences recorded that the isolates from those countries collected from different species of fishes not from sea bream fish.

In the Mediterranean Sea, the major constraints in aquaculture of sea bream were LCDV as stated by García-Rosado et al. (2007). Since the 1980s, LCDV has been reported in different countries of the Northern Mediterranean coasts as recorded by Menezes et al. (1987); Le Deuff and Renault (1993). In the Southern coasts, only a partial MCP sequence was reported in Tunisia in 2005, but with no information about its epidemiological impact or its geographic origin as mentioned by Cano et al. (2010). LCDV has been reported more than 100 different marine and freshwater fish species, it seems obvious that, the existence of differences regarding the viral genome structure, gene organization and DNA sequence depending on the host fish or the geographical location as indicated by Kitamura et al. (2005). In fact, although MCP gene is highly conserved and contains sufficient variable regions to allow phylogenetic analysis, the use of different genes may be more significant to trace the epidemiological origin in such a 
context. Unfortunately, this analysis requires availability of relevant sequences of entire LCDV genome but currently a few number of LCDV genome sequences are available (Haddad-Boubaker et al., 2013).

\section{Conclusion}

The present study revealed detection of LCDV from sea bream fish cultured in Egypt that might constitute a negative impacts on the national economy.

Gross lesion and histopathology may aid in diagnosis of LCDV among fish however, molecular detection; PCR and sequencing as well as phylogenetic analysis confirm the diagnosis.

The active international trade with lack implementation for strict regulations regarding fish transfer between countries may be responsible for the dissemination of viral strains, especially in the absence of a certification as free stocks.

The current results recommend further studies for the diagnosis and development of preventive measures and control strategies against LCDV in sea bream fish in Egypt.

\section{References}

Aly, S. (2013): A Review of Fish Diseases in the Egyptian Aquaculture Sector. Working Report.

Borrego, J.J.; Castro, D.; Balebona, M.C.; Garcia-Rosado, E. and Lopez-Cortes, L. (2001):
Patologías que Afectan al Cultivo de la Dorada (Sparus aurata, L.) en la Comunidad Autónoma Andaluza. Editada por la Consejería de Agricultura y Pesca, Junta de Andalucía, Sevilla, España.

Bowden, R.A.; Oestmann, D.J.; Lewis, D.H. and Frey, M.S. (1995): Lymphocystis in Red Drum. J. Aquat. Anim. Health, 7(3): 231-235. doi:10.1577/15488667(1995)007<0231:LIRD>2.3.C $\mathrm{O} ; 2$

Cano, I.; Ferro, P.; Alonso, M.C.; Sarasquete, C.;Garcia-Rosado, E., Borrego, J.J. and Castro, D. (2009): Application of in situ detection techniques to determine the systemic condition of lymphocystis disease virus (LCDV) infection in cultured gilt-head seabream, Sparus aurata L. J. Fish Dis. 32: 143-150. doi: 10.1111/j.1365-2761.2008.00970.x.

Cano, I.; Valverde, E. J.; LopezJimena, B.; Alonso, M. C.; Garcia-Rosado, E.; Sarasquete, C.; Borrego, J. J. and Castro, D. (2010): A new genotype of lymphocystivirus isolated from cultured gilthead seabream, Sparus aurata L., and Senegalese sole, Solea senegalensis (Kaup). J. Fish Dis., 33: 695-700.

Colorni, A. and Padrós, F. (2011): Diseases and health management. In: Sparidae: Biology and Aquaculture of Gilthead Sea Bream and other Species, edited by M.A. Pavlidis \& C.C. Mylonas, pp. 321357. Wiley-Blackwell, Oxford, United Kingdom. 
Colorni, A. and Padrós, F. (2011): Diseases and health management. In: Sparidae: Biology and Aquaculture of Gilthead Sea Bream and other Species, edited by M.A. Pavlidis \& C.C. Mylonas, pp. 321357. Wiley-Blackwell, Oxford, United Kingdom.

Dezfuli, B.S.; Lui, A.; Giari, L.; Castaldelli, G.; Mulero, V. and Noga, E.J. (2012): Infiltration and activation of acidophilic granulocytes in skin lesions of gilthead seabream, Sparus aurata, naturally infected with lymphocystis disease virus. Dev. Comp. Immunol; 36: 174-182. doi: 10.1016/j.dci.2011.06.017.

García-Rosado, E.; Cano, I.; Martín-Antonio, B.; Labella, A.; Manchado, M.; Alonso, M. C.; Castro, D. and Borrego, J. J. (2007): Co-occurrence of viral and bacterial pathogens in disease outbreaks affecting newly cultured sparid fish. Int. microbiol., 10: 193199.

Gonzalez de Canales, M.L.; Munoz-Cueto, J.A.; Arellano, J.; García-Garcia, A. and Sarasquete, C. (1996): Histological and histochemical characteristics of the lymphocystis disease in gilthead sea bream, Sparus aurata, L. from the South-Atlantic coast of Spain. European Journal of Histochemistry 40: 143-152.

Haddad-Boubaker, Bouzgarou, N.; Fakhfakh, E.; Khayech, M.; Mohamed, S.B.; Megdich, A. and Chéhida, N.B. (2013): Detection and genetic characterization of lymphocystis disease virus (LCDV) isolated during disease outbreaks in cultured gilt-head sea bream Sparus aurata in Tunisia. Fish Pathol.; 48: 101-104. doi: 10.3147/jsfp.48.101.

Iwamoto, R.; Hasegawa, O.; LaPatra, S. and Yoshimizu, M. (2002): Isolation and characterization of the Japanese flounder (Paralichthys olivaceus) lymphocystis disease virus. J. Aquat. Anim. Health, 14: 114-123. Jancovich, J.K.; Chinchar, V.G.; Hyatt, A.; Miyazaki, T.; Williams, T. and Zhang, Q.Y. (2012): Family Iridoviridae. In: Virus Taxonomy: Ninth Report of the International Committee on Taxonomy of Viruses. Edited by. A.M.Q. King, M.J. Adams, E.B. Carstens \& E.J. Lefkowitz. pp. 193 210. Elsevier Academic Press, San Diego.

Kitamura, S.I.; Jung, S.J.; Kim, W.S.; Nishizawa, T.; Yoshimizu, M. and Oh, M.J. (2005): A new genotype Lymphocystis, LCDVRF, from lymphocytes diseased rockfish. Arch. Virol., 151: 607615.

Kvitt, H.; Heinisch, G. and Diamant, A. (2008): Detection and phylogeny of Lymphocystivirus in sea bream Sparus aurata based on the DNA polymerase gene and major capsid protein sequences. Aquaculture, 275: 58-63.

Le Deuff, R.M. and Renault, T. (1993): Lymphocystis outbreaks in farmed seabream, Sparus aurata, first report on French 
Mediterranean coast. Bulletin of the European Association of Fish Pathologists 13: 130-133.

Mao, J.; Hedrick, R.P. and Chinchar, V.G. (1997): Molecular characterization, sequence analysis and taxonomic position of newly isolated fish iridoviruses. Virology 229: 212-220.

Mello, M.V.; Aragao, M.E.; Torres-Franklin, M.L.; Neto, J.M. and Guedes, M.I. (2011): Purification of infectious myonecrosis virus (IMNV) in species of marine shrimp Litopenaeus vannamei in the State of Ceara. J Virol Methods, 177(1): $10-14$

doi:10.1/016j.jviromet.2011.05.032

Menezes, J.; Ramos, A. and Pereira, T.G. (1987): Lymphocystis disease: an outbreak in Sparus aurata from Ria Formosa, south coast of Portugal. Aquaculture, 67: 222-225.

Michaelsen, K.F.; Dewey, K.G.; Perez-Exposito, A.B.; Nurhasan, M.; Lauritzen, L. and Roos, N. (2011): Food sources and intake of n-6 and n-3 fatty acids in lowincome countries with emphasis on infants, young children (6-24 months), and pregnant and lactating women. Maternal Child Nutr. 7(Suppl.2): 124-140.

Mosharrof Hossain and MyungJoo Oh (2011): Histopathology of marine and freshwater fish lymphocystis disease virus (LCDV). Sains Malaysiana, 40(10): pp. 1049-1052. ISSN 0126-6039.
Mustapha, A.; Driss, B. and Mohamed, B. (2014): The main species of freshwater fish aquaculture interest in Morocco, current status and prospects. Int. J. Fish. Aquat. Stud., 2(1): 216-218.

Paperna, I.; Vilenkin, M. and Alves de Matos, A.P. (2001): Iridovirus infections in farm-reared tropical ornamental fish. Dis Aquat Org 48: 17-25

Paperna, I.; Ilana-Sabnai, H. and Colorni, A. (1982): An outbreak of lymphocystis in Sparus aurata L. in the Gulf of Aqaba, Red Sea. Journal of Fish Diseases, 5(5): 433-437. doi:10.1111/j.13652761.1982.tb00500.x

Poulos, B.T. and Lightner, D.V. (2006): Detection of infectious myonecrosis virus (IMNV) of penaeid shrimp by reversetranscriptase polymerase chain reaction (RT-PCR). Dis. Aquat. Org., 73: 69-72.

Rodger, G.K. and Davies, I.M. (2000): Summary of mariculture production in countries neighbouring the European Union. J. Appl. Ichthyol., 16(45): 224-229. Shaalan, M.; El-Mahdy, M.; Saleh, M. and El-Matbouli, M. (2018): Aquaculture in Egypt: Insights on the Current Trends and Future Perspectives for Sustainable Development. Reviews in Fisheries Science \& Aquaculture, 26(1): 99110. DOI: 10.1080/23308249.2017.1358696

Shackelford, C.; Long, G.; Wolf, J.; Okerberg, C. and Herbert, R. (2002): Qualitative and quantitative 
analysis of nonneoplastic lesions in toxicology studies. Toxicol Pathol. 30(1): 93-6.

Sheng, X.Z. and Zhan, W.B. (2004): Occurrence, development and histochemical characteristics of lymphocystis in cultured Japanese flounder (Paralichtys olivaceous). High Technology Letters 10: 92-96. Suvarna, S.K.; Layuton, C. and Bancroft, J.D. (2013): Bancroft's theory and practice of histological techniques. 7th edition, Churchill Livingstone Press, New York, USA. Tacon, A.G.J. and Metian, M. (2013): Fish matters: importance of aquatic foods in human nutrition and global food supply. Rev. Fish. Sci. 21(1): 22-38.

Thilsted, S.H. (2013): Fish diversity and fish consumption in Bangladesh. In: Fanzo, J., Hunter, D., Borelli, T., Mattei, F. (Eds.), Diversifying Food and Diets: Using Agricultural Biodiversity to Improve Nutrition and Health. Earthscan, London.

Tidona, C.A. and Darai, G. (1999): Lymphocystis disease virus (Iridoviridae). In: Granoff A, Webster RG (eds) Encyclopedia of Virology, 2nd edn, pp. 908-911. Academic Press, New York.

Verônyca Coelho-Melo, M.; Florindo Guedes, M.I.;
Rodriguez-Málaga, S.; Magalhaes De Almeida, L.; De Freitas Moreira, M. and Rodrigues De Oliveira, T. (2014): Molecular characterization of Infectious Myonecrosis Virus (IMNV) isolated from the shrimp Litopenaeus vannamei farmed in Ceará state, Brazil. Latin American Journal of Aquatic Research, 42(3): 649-652.

Walker, P. J. and Winton, J. R. (2010): Emerging viral diseases of fish and shrimp. Vet Res, 41(6): 51. doi: 10.1051/vetres/2010022

Wang, Q.; Cheng, L.; Liu, J.; Li, Z.; Xie, S. and De Silva, S. S. (2015): Freshwater aquaculture in PR China: Trends and prospects. Rev. Aquacult., 7(4): 283-302.

Wolf, K. (1988): Lymphocystis disease. In: Fish Viruses and Fish Viral Disease. Edited by K. Wolf, pp. 268-291. Ithaca: Cornell University Press, New York, EE.UU.

World Bank, (2006): Aquaculture: Changing the Face of the Waters: Meeting the Promise and Challenge of Sustainable Aquaculture. World Bank, Washington, DC.

Xing, J.; Sheng, X. and Zhan, W. (2006): Lymphocystis disease and diagnostic methods in China. Aquaculture Asia Magazine, January-March: 30-33. 


\section{التوصيف الباثولوجى والجزيئى لفيروس الحويصلات الليمفاوية في أسماك الانيس البحري في مصر الجريصرات}

صلاح الدين مصيلحي على1, شيماء محمد منصور , ر رندا يسري ثابت3

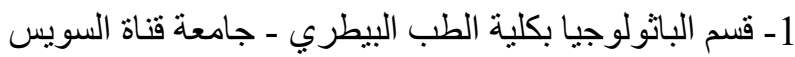

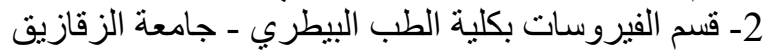

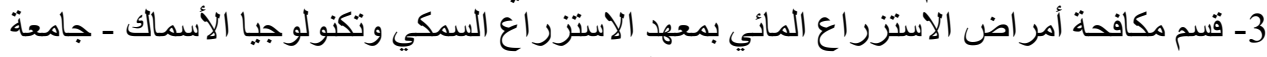
قناة السويس

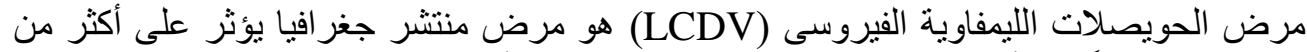

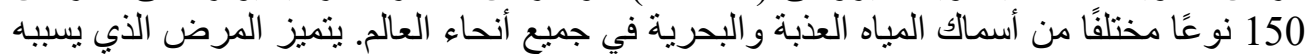

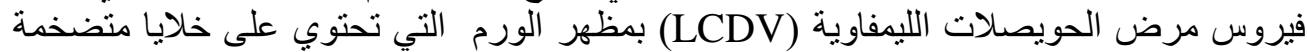

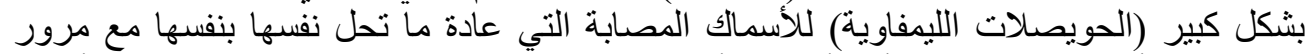

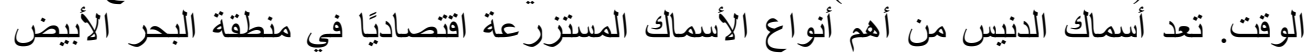

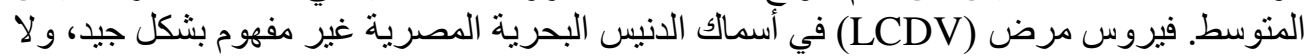

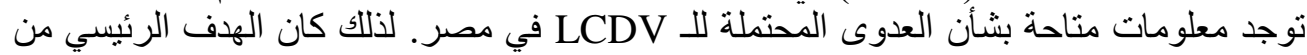

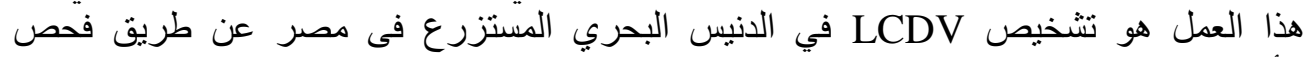

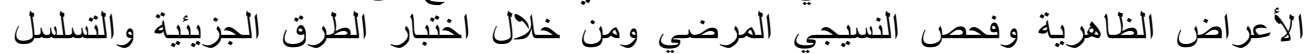

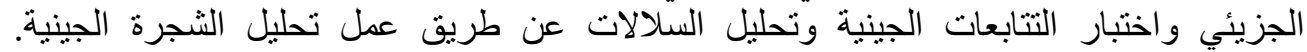

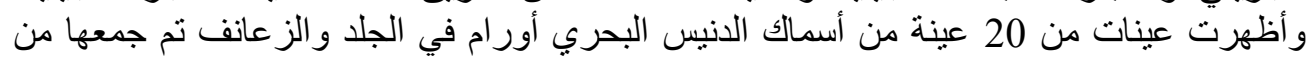

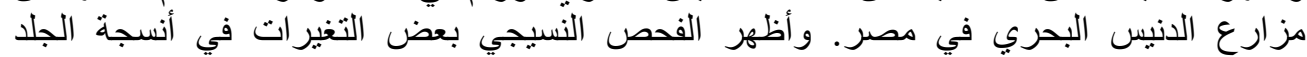

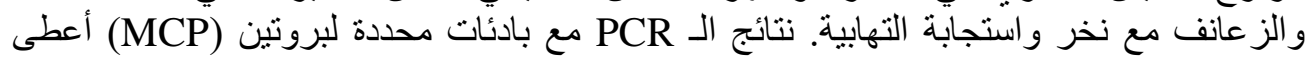

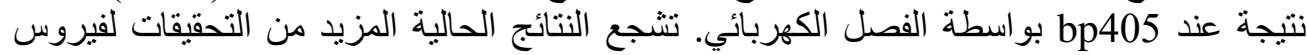

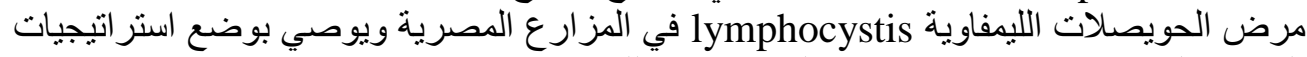

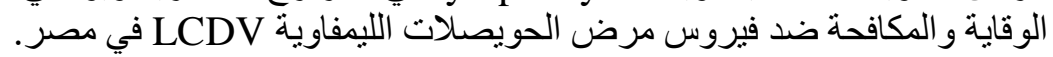

الكلمات الافتتاحية: الدنيس، مصر، فيروس مرض الحويصلات الليمفاوية، الفحص المرضي للأنسجة، الفحص الجزيئي، تفاعل البلمرة المتسلسل، الثجرة الجينية. 